\title{
Ocean biogeochemistry exhibits contrasting responses to a large scale reduction in dust deposition
}

\author{
A. Tagliabue ${ }^{1}$, L. Bopp ${ }^{1}$, and O. Aumont ${ }^{2}$ \\ ${ }^{1}$ Laboratoire des Sciences du Climat et de l'Environnement, IPSL-CNRS-CEA-UVSQ Orme des Merisiers, Bat 712, \\ CEA/Saclay, 91198 Gif sur Yvette, France \\ ${ }^{2}$ Laboratoire d'Océanographie et Climatologie: Expérimentation et Approches Numériques, IRD/IPSL, Plouzané, France
}

Received: 12 July 2007 - Published in Biogeosciences Discuss.: 2 August 2007

Revised: 13 November 2007 - Accepted: 5 December 2007 - Published: 11 January 2008

\begin{abstract}
Dust deposition of iron is thought to be an important control on ocean biogeochemistry and air-sea $\mathrm{CO}_{2}$ exchange. In this study, we examine the impact of a large scale, yet climatically realistic, reduction in the aeolian $\mathrm{Fe}$ input during a 240 year transient simulation. In contrast to previous studies, we find that the ocean biogeochemical cycles of carbon and nitrogen are relatively insensitive (globally) to a $60 \%$ reduction in $\mathrm{Fe}$ input from dust. Net primary productivity (NPP) is reduced in the Fe limited regions, but the excess macronutrients that result are able to fuel additional NPP elsewhere. Overall, NPP and air-sea $\mathrm{CO}_{2}$ exchange are only reduced by around $3 \%$ between 1860 and 2100 . While the nitrogen cycle is perturbed more significantly (by $\sim 15 \%$ ), reduced $\mathrm{N}_{2}$ fixation is balanced by a concomitant decline in denitrification. Feedbacks between $\mathrm{N}_{2}$ fixation and denitrification are controlled by variability in surface utilization of inorganic nitrogen and subsurface oxygen consumption, as well as the direct influence of $\mathrm{Fe}$ on $\mathrm{N}_{2}$ fixation. Overall, there is relatively little impact of reduced aeolian $\mathrm{Fe}$ input $(<4 \%)$ on cumulative $\mathrm{CO}_{2}$ fluxes over 240 years. The lower sensitivity of our model to changes in dust input is primarily due to the more detailed representation of the continental shelf $\mathrm{Fe}$, which was absent in previous models.
\end{abstract}

\section{Introduction}

The necessary nutrients for phytoplankton growth, including nitrogen $(\mathrm{N})$, phosphorous $(\mathrm{P})$, silica $(\mathrm{Si})$, and iron $(\mathrm{Fe})$, can be supplied to ocean surface waters via the aeolian deposition of mineral aerosols (Duce et al., 1991). Of these, Fe has received particular interest, due to its potential to influence the cycle of carbon $(\mathrm{C})$ in climatically significant regions of the worlds oceans (Jickells et al., 2005). Total dust inputs to the

Correspondence to: A. Tagliabue

(alessandro.tagliabue@1sce.ipsl.fr) ocean are on the order of $450 \mathrm{Tg} \mathrm{yr}^{-1}$ (Ginoux et al., 2001; Mahowald and Luo, 2003; Tegen et al., 2004) and usually contain around $3.5 \% \mathrm{Fe}$, with a solubility that can be highly variable (e.g., Jickells and Spokes, 2001). Phytoplankton are limited by Fe in the "high nutrient, low chlorophyll" (HNLC) ocean regions, such as the Southern Ocean (Boyd et al., 2000), Equatorial Pacific (Coale et al., 1996) and Sub Arctic Pacific (Boyd et al., 2004) and elevated oceanic dust deposition to the Southern Ocean might drive Glacial-Inter Glacial atmospheric $\mathrm{CO}_{2}$ variability (Martin, 1990). Oceanic dust deposition has likely declined from the pre industrial (PI) to the present day (Mahowald et al., 2006). Predictions of future deposition are model dependent and will be controlled by land use changes, as well as climate effects (Tegen et al., 2004; Mahowald et al., 2006; Mahowald, 2007). Processes that impact sources areas and dust loading, such as $\mathrm{CO}_{2}$ fertilization, have the potential to drive dramatic reductions in oceanic dust deposition over the coming century (Mahowald et al., 2006).

Variability in the atmospheric deposition of Fe can significantly impact $\mathrm{C}$ biogeochemistry. Phytoplankton require Fe for a variety of photosynthetic and respiratory enzymes (Falkowski et al., 1998; Raven, 1990) and changes in exogenous Fe supply will therefore directly impact net primary production (NPP) and the fixation of inorganic C. Moreover, the amount of $\mathrm{Fe}$ that is required to fix a given quantity of $\mathrm{C}$ is greater under low irradiance (Sunda and Huntsman, 1997; Raven, 1990) and nitrate $\left(\mathrm{NO}_{3}\right)$ based growth (Raven, 1990), as well as for large phytoplankton functional groups (Timmermans et al., 2004). Accordingly, all HNLC mesoscale $\mathrm{Fe}$ addition experiments have elicited increases in large diatoms, which can efficiently export fixed $\mathrm{C}$ to depth, and are more efficient (per unit Fe added) in shallow mixed layers (De Baar et al., 2005; Tagliabue and Arrigo, 2006). Atmospheric $\mathrm{pCO}_{2}$ might increase dramatically (via a decline in both NPP and air to sea $\mathrm{CO}_{2}$ transfer) if the aeolian input of $\mathrm{Fe}$ were to decrease significantly over the coming decades

Published by Copernicus Publications on behalf of the European Geosciences Union. 
(Moore et al., 2006; Parekh et al., 2006), although other studies show a much lower sensitivity (Bopp et al., 2003).

Aside from its direct impact on $\mathrm{C}$ fixation, the aeolian input of Fe can also influence the biogeochemistry of N. Nitrogenase, the enzyme responsible for fixation of dinitrogen $\left(\mathrm{N}_{2}\right)$ by phytoplankton, has a large Fe requirement (Rueter et al., 1992) and this has led to speculation that $\mathrm{N}$ fixation might be regulated by $\mathrm{Fe}$ and sensitive to variability in aeolian inputs (Falkowski, 1997; Moore and Doney, 2007). As such, increased $\mathrm{N}_{2}$ fixation can elevate surface dissolved inorganic $\mathrm{N}$ (DIN) concentrations, potentially increasing overall NPP and the uptake of $\mathrm{CO}_{2}$ from the atmosphere (Falkowski et al., 1997; Michaels et al., 2001; Moore and Doney, 2007). That said, it is also important to consider how changes in Fe deposition might impact processes that govern the losses of DIN. During denitrification, bacteria utilize $\mathrm{NO}_{3}$, as an alternative electron acceptor for remineralization under low oxygen conditions. $\mathrm{N}_{2}$ fixation and denitrification are therefore coupled by their generation and consumption of DIN and analyses of both models and observations have suggested a balanced, or homeostatic, DIN inventory (Redfield, 1934; Gruber and Sarmiento, 1997; Tyrrell, 1999; Gruber, 2004; Deutsch et al., 2007). Nevertheless, this concept remains controversial (see: Codispoti, 2007) and, with particular reference to dust, Fe has been proposed to be an agent that can unbalance the N cycle (Moore and Doney, 2007).

In this study we use the Pelagic Integration Scheme for Carbon and Ecosystem studies (PISCES) global oceanbiogeochemistry model (Aumont and Bopp, 2006) to examine the response of ocean biogeochemistry to a reduction in aeolian Fe input during a transient simulation from 1860 to 2100. We use climatically realistic projections from Mahowald et al. (2006) (rather than arbitrary changes) to investigate the biogeochemical consequences of such an extreme change. Previously, models using either simple ecosystem dynamics or performing short term simulations have shown a high sensitivity to changes in dust deposition (Dutkiewicz et al., 2005; Parekh et al., 2006; Moore et al., 2006). In contrast, we find that the biogeochemical cycles of $\mathrm{C}$ and $\mathrm{N}$ are actually relatively insensitive (globally) to a massive reduction in dust input during a transient simulation from 1860 to 2100. While $\mathrm{N}_{2}$ fixation is more significantly impacted by reduced dust inputs, it is also accompanied by a concomitant decline in denitrification, which stabilizes ocean DIN inventories. The disparity in model results is discussed in terms of inter-model differences in the ocean Fe cycle and the timescales over which the particular study is evaluated.

\section{Methods}

\subsection{The PISCES model}

The PISCES ocean-biogeochemistry model is extensively described in Aumont and Bopp (2006) and includes two phytoplankton functional groups (nanophytoplankton and diatoms), meso- and micro-zooplankton, 2 detrital size classes for particulate organic carbon (POC), calcium carbonate, silicic acid $\left(\mathrm{Si}(\mathrm{OH})_{4}\right)$, DIC, biogenic $\mathrm{Si}$, dissolved organic $\mathrm{C}$, $\mathrm{NO}_{3}$, phosphate $\left(\mathrm{PO}_{4}\right)$, Silicic acid $\left(\mathrm{Si}(\mathrm{OH})_{4}\right)$, ammonium $\left(\mathrm{NH}_{4}\right)$, and $\mathrm{Fe}$. Here we describe the parameterizations relevant for this study.

\subsection{Net primary production, species composition and gas exchange}

In order to calculate net primary productivity (NPP) we first calculate a maximum phytoplankton specific growth rate $\left(\mu_{\max }\right)$ for each phytoplankton functional type (PFT) that is a function of temperature. $\mu_{\max }$ is then scaled by the product of the most limiting nutrient (assuming Michaelis Menten kinetics) and the light (using the initial slope of the P-E relationship, including photoadaptation) limitation terms to produce the realized specific growth rate $(\mu)$, and $\mathrm{C}$ fixation rate of each PFT. The half saturation constant for growth $(\mathrm{K} \mu)$ is fixed for all nutrients except $\mathrm{Fe}$, where it varies as a function of biomass (taken as a proxy for cell size). The uptake of $\mathrm{NO}_{3}$ and $\mathrm{PO}_{4}$ that accompanies NPP is calculated assuming fixed Redfield ratios $(\mathrm{C} / \mathrm{N}=122 / 16$ and $\mathrm{C} / \mathrm{P}=122 / 1)$. On the other hand, the $\mathrm{Fe} / \mathrm{C}$ ratio increases as light declines and decreases with $\mathrm{Fe}$ stress, while $\mathrm{Si} / \mathrm{C}$ decreases as light increases and also permits lighter silicification if $\mathrm{Si}(\mathrm{OH})_{4}$ concentrations decline.

Each PFT has certain specific physiological characteristics that will govern their response to our imposed changes in aeolian $\mathrm{Fe}$ deposition. Diatoms are assumed to have a requirement for $\mathrm{Si}(\mathrm{OH})_{4}$ (no such requirement for nanophytoplankton) and a higher $\mathrm{K} \mu$ (relative to nanophytoplankton) for $\mathrm{NH}_{4}, \mathrm{PO}_{4}$, and $\mathrm{Fe}$, but a lower $\mathrm{K} \mu$ for $\mathrm{NO}_{3}$ Diatoms also have a greater maximum and minimum $\mathrm{C}$-specific $\mathrm{Fe}$ demand and $\mathrm{K} \mu \mathrm{Fe}$ than nanophytoplankton. Finally, nanophytoplankton support a more regenerative food web, producing small particles and being preferentially grazed by microzooplankton. In contrast, mesozooplankton have a preference for diatoms and microzooplankton grazing of diatoms is zero when their biomass is greater than $0.5 \mu \mathrm{mol} \mathrm{Cl} l^{-1}$. Diatoms also produce large, rapidly sinking particles.

The air-sea exchange of $\mathrm{CO}_{2(\mathrm{aq})}$ follows the OCMIP protocols and is a function of the air-sea $\mathrm{pCO}_{2}$ gradient, temperature, ice-cover, and the piston velocity. We represent the wind speed dependence of the piston velocity via a quadratic function of the wind speed at $10 \mathrm{~m}$ (Wanninkhof, 1992).

The $\mathrm{Fe}$ cycle is represented in a relatively simple fashion and dissolved $\mathrm{Fe}$ is assumed to be made up of free inorganic and organically complexed $\mathrm{Fe}$, both of which are bioavailable. The concentration of organically complexed $\mathrm{Fe}$ is computed using a chemical equilibrium constant and a fixed ligand concentration of $0.6 \mathrm{nM}$. The impact of abiotic Fe chemistry (e.g., Tagliabue and Arrigo, 2006) on Fe speciation and bioavailable $\mathrm{Fe}$ concentrations is not included. 
Free inorganic Fe can be converted to particulate species by scavenging onto particles. Atmospheric deposition of Fe assumes that $\mathrm{Fe}$ is $3.5 \%$ of dust, with a solubility of $0.5 \%$ and includes subsurface dissolution of dust particles. Additional sources of $\mathrm{Fe}$ are sediment resuspension, which includes a representation of continental shelf supply that is usually ignored by global models (Aumont and Bopp, 2006), as well as riverine supply (hydrothermal sources are not represented in PISCES). For reference, the annual integrated aeolian and sediment sources of Fe are shown in Fig. 1a and b.

The fundamentals of the PISCES Fe cycle processes remain the same as previously detailed in Aumont and Bopp (2006). The greater overall dust deposition in the newer fields of Mahowald et al. (2006) necessitated a reduction in the solubility of $\mathrm{Fe}$ from 1 to $0.5 \%$, which is at the low end of previously published models (usually around $1 \%$, e.g., Dutkiewicz et al., 2005; Moore and Doney, 2007) and the observations of up to 20 or $30 \%$ (e.g., Jickells and Spokes, 2001), in order to retain realistic distributions of NPP and biogeochemical tracers. On the other hand, a recent study (Sedwick et al., 2007) found the solubility of Saharan and anthropogenic aerosols to be 0.44 and $19 \%$, respectively, which suggests $0.5 \%$ to be not completely unreasonable. We calculated correlation coefficients ( $R$, after log transformation) and the root mean squared error (RMSE) between the modeled and observed dFe at depths of 0 to $50 \mathrm{~m}, 100$ to $300 \mathrm{~m}$ and 2000 to $3000 \mathrm{~m}$. In surface waters, monthly calculations yield values for $R$ that range between 0.41 (in October) and 0.79 (in August), with a mean of 0.61. Ten months are statistically significant at the $p<0.01$ level, while December is significant at $0.01>p<0.05$ and February not significant due to the paucity of data $(R=0.62$, but there are only 6 observations). In subsurface and deep waters, $R$ is 0.63 and 0.77 between 100 and $300 \mathrm{~m}$ and 2000 and $3000 \mathrm{~m}$, respectively. RMSE values are $0.47,0.35$ and 0.3 for 0 to $50 \mathrm{~m}, 100$ to $300 \mathrm{~m}$ and 2000 to $3000 \mathrm{~m}$, respectively. For comparison, Moore and Braucher (2007) report $R$ and RMSE values of 0.598 and 0.443 , and 0.602 and 0.338 for depth ranges of 0 to $103 \mathrm{~m}$ and 103 to $502 \mathrm{~m}$, respectively.

\subsection{Nitrogen cycling in PISCES}

The uptake of DIN by phytoplankton and subsequent remineralization of organic matter to DIN is described in $\mathrm{Au}-$ mont and Bopp (2006), here we concentrate on describing $\mathrm{N}_{2}$ fixation and denitrification. In previous versions of PISCES (e.g., Aumont and Bopp, 2006), $\mathrm{N}_{2}$ fixation was artificially linked to the annual rate of dentrification and were therefore explicitly coupled. This linkage is not present in the current study.

Marine $\mathrm{N}_{2}$ fixation is carried out by numerous planktonic organisms, including the oft mentioned Trichodesmium sp., as well as a variety of unicellular diazotrophes, croccosphera and diatom endosymbionts (see: Mahaffey et al., 2005 and references therein). Given this taxonomic diversity and

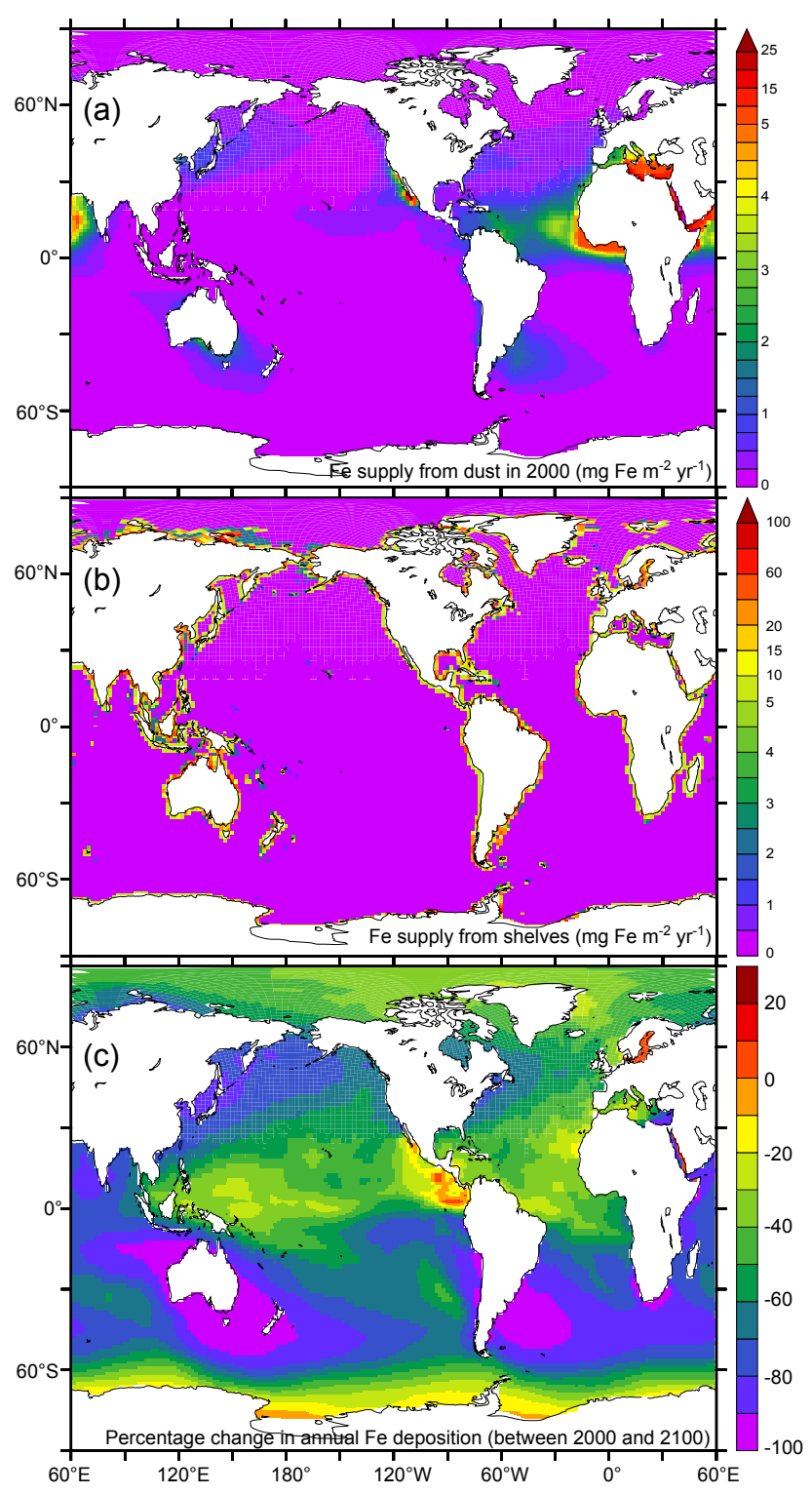

Fig. 1. The annual supply of Fe to the ocean in 2000 from (a) dust, (b) continental shelves and (c) the percentage change in the oceanic Fe deposition from the atmosphere between 2000 and 2100.

the associated physiological variability, we decided not to prognostically simulate a $\mathrm{N}_{2}$ fixing plankton functional type (PFT) within PISCES. Instead, we chose to include $\mathrm{N}_{2}$ fixation as a process that produces $\mathrm{NH}_{4}$ under certain conditions (Aumont and Bopp, 2006). Specifically, $\mathrm{N}_{2}$ fixation is a function of the growth rate of the nanophytoplankton function group and only occurs in surface waters that have a temperature warmer than, or equal to, $20^{\circ} \mathrm{C}$. This maximum potential rate of $\mathrm{N}_{2}$ fixation is then scaled by the limitation term for $\mathrm{Fe}$ and one minus the limitation term for DIN $\left(\mathrm{NO}_{3}\right.$ and $\left.\mathrm{NH}_{4}\right)$. Therefore, the realized rate of $\mathrm{N}_{2}$ fixation increases with decreasing DIN and declines as Fe becomes more limiting. 
Denitrification occurs in suboxic waters and results in $\mathrm{NO}_{3}$ instead of $\mathrm{O}_{2}$ being consumed during the remineralization of organic matter. In PISCES, we restrict denitrification to waters whose $\mathrm{O}_{2}$ concentration is below $8 \mu \mathrm{M}$ (Lipshultz et al., 2000) and set the N/C stiochiometric ratio for denitrification to be $0.8 \mathrm{~mol}$ : mol (Middelburg et al., 1996; Soetaert et al., 2000). Finally, we also include the bacterial conversion of $\mathrm{NH}_{4}$ to $\mathrm{NO}_{3}$ via nitrification, which occurs in oxic waters and is inhibited by light.

Despite our relatively simple parameterization scheme, denitrification and $\mathrm{N}_{2}$ fixation are implicitly coupled in PISCES. Although we do not include a diazotrophic PFT in PISCES, we do include the main role of $\mathrm{N}_{2}$ fixation in supplying $\mathrm{NH}_{4}$ under certain conditions. The absence of an explicit PFT might be important if diazotrophes are significantly different in their sinking and remineralization characteristics, or food web structure; all of which are currently difficult to generalize for use in a global model. This approach also assumes that $\mathrm{N}_{2}$ fixers exhibit the same physiology as the nanophytoplankton PFT. Variability in denitrification will alter DIN concentrations which will, in turn, impact the rate of $\mathrm{N}_{2}$ fixation. While on the other hand, changes in export production (mediated by $\mathrm{N}_{2}$ fixation and/or Fe and other nutrients) will modify subsurface $\mathrm{O}_{2}$ concentrations and thus denitrification rates. This approach also allows the long spin up and simulation periods to be conducted with a relatively low computational cost.

\subsection{Physical model}

The physical model coupled to PISCES is based on the ORCA2 global configuration of OPA version 8.2 (Madec et al., 1998), including a dynamic-thermodynamic sea ice model (Timmermann et al., 2003). The mean horizontal resolution is approximately $2^{\circ}$ by $2^{\circ} \cos$ latitude and the meridional resolution is enhanced to $0.5^{\circ}$ at the equator. The model has 30 vertical levels, with an increment that increases from $10 \mathrm{~m}$ at the surface to $500 \mathrm{~m}$ at depth (12 levels are located in the first $125 \mathrm{~m}$ ). Our standard physical model employs climatological atmospheric forcing from various datasets. These include NCEP/NCAR $2 \mathrm{~m}$ atmospheric temperature (averaged between 1948 and 2003) and relative humidity, ISCCP total cloudiness (averaged between 1983 and 2001), CMAP precipitation (averaged between 1979 and 2001), weekly wind stress based on ERS and TAO observations and creates a representation of ocean circulation/mixing that is constrained by observations. Please see Aumont and Bopp (2006) for more details and the associated references.

\subsection{Experimental design}

After spinning up the model for over 3000 years under preindustrial conditions, we ran PISCES for a 240 year period from 1860 to 2100 with a specified atmospheric $\mathrm{pCO}_{2}$ that is constrained by observations between 1860 and 2000
(Keeling et al., 2001) and the A2 scenario from 2000 to 2100 (Nakicenovic and Swart, 2000). A recent study by Mahowald et al. (2006) used the National Center for Atmospheric Research's Community Climate System Model (NCAR-CCSM) to investigate the change in mineral aerosols in response to climate and predict pre industrial, current, and future dust sources, as well as oceanic deposition. We linearly interpolated the aeolian Fe supply to the ocean between the pre industrial (1860), current (taken to be 2000) and doubled $\mathrm{CO}_{2}$ (taken as 2100) fields of Mahowald et al. (2006), and assume Fe to be $3.5 \%$ of dust, with a solubility of $0.5 \%$. Only the atmospheric $\mathrm{CO}_{2}$ concentration and dust deposition change during our scenario (all other forcings remain constant). We also ran a control experiment from 1860 to 2100 that was forced by the annually changing atmospheric $\mathrm{pCO}_{2}$ concentrations, but constant PI dust deposition. Finally, we use the year 2000 as a reference, as it represents 'modern' dust deposition.

\section{Results and discussion}

\subsection{Changes in aeolian Fe input in 2100}

The predicted reduction in aeolian Fe input in 2100 (relative to 2000) is spatially heterogenous and results from changes in sources area and dust loading (see: Mahowald et al., 2006). The largest percentage reductions in aeolian $\mathrm{Fe}$ input are found throughout the sub-Antarctic Southern Ocean, specifically to the south of Australia, Patagonia and, to a lesser degree, South Africa (Fig. 1). In the remaining HNLC regions (the sub-Arctic and Equatorial Pacific) there are slightly lesser, but still significant, reductions in $\mathrm{Fe}$ deposition (Fig. 1). It is noteworthy that the locations where a proportionally high reduction in dust is predicted are all HNLC regions of relatively high NPP. Aside from that, there are also large absolute reductions in Fe deposition in the Northern Subtropical Atlantic Ocean (Fig. 1). The decline in dust deposition is due to the predicted decline in future dust loading that results from climate induced changes in precipitation, temperature and cloudiness, as well as $\mathrm{CO}_{2}$ fertilization (Mahowald et al., 2006; but see Mahowald, 2007 for a discussion of various model predictions). Between the preindustrial and modern periods, the decline in dust deposition is controlled by changes in source area, mostly at southerly latitudes (Mahowald et al., 2006). Quantitatively, this represents a reduction in total aeolian $\mathrm{Fe}$ deposition to ocean surface waters of $38 \%$ and $60 \%$ by 2000 and 2100 , respectively (relative to 1860). We are interested in how ocean biogeochemistry (in particular the cycles of $\mathrm{C}$ and $\mathrm{N}$ ) might respond to a realistic reduction in deposition that is generated by a climate model, rather than an arbitrary change in model forcings (halving, or eliminating dust deposition, for example). 

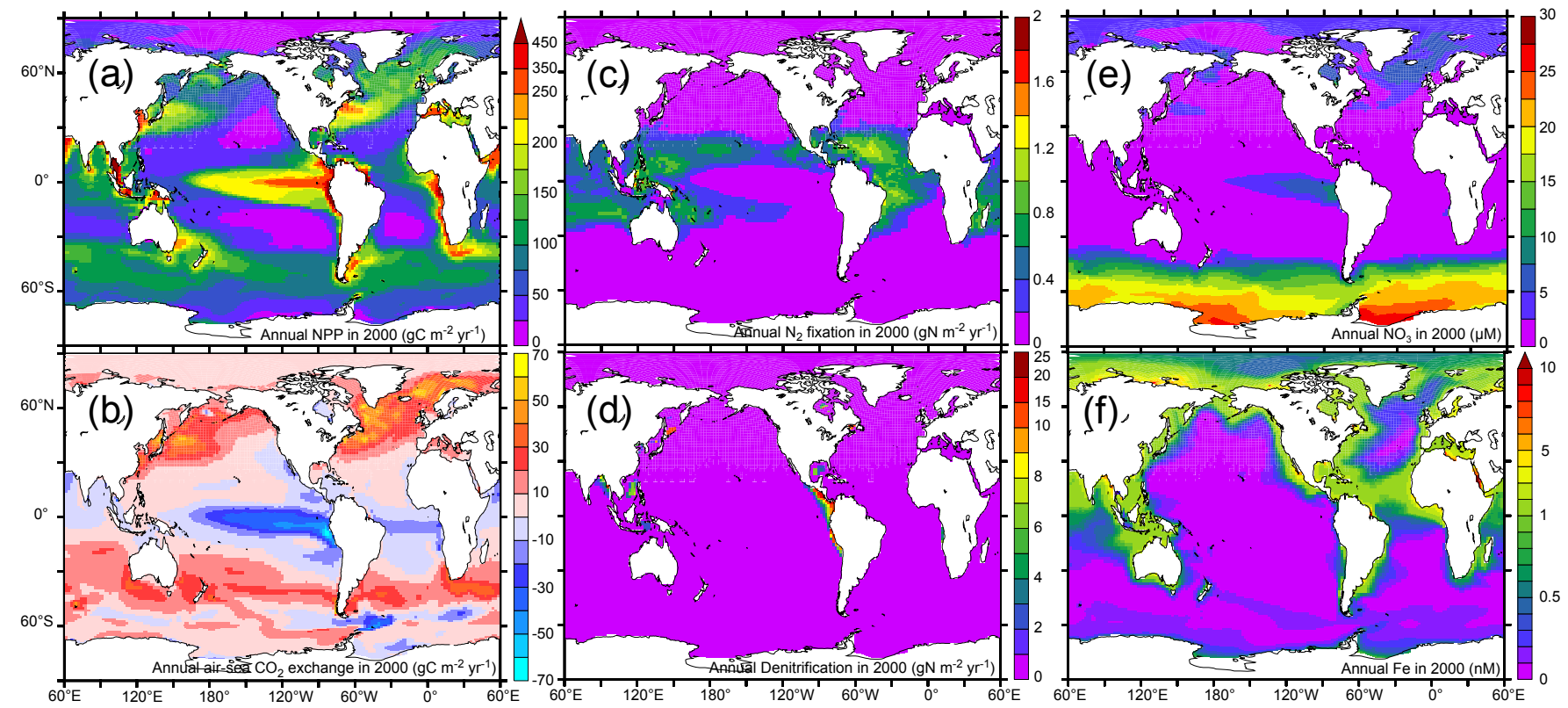

Fig. 2. The annual rate of (a) NPP $\left(\mathrm{gC} \mathrm{m}^{-2} \mathrm{yr}-1\right)$, (b) air-sea $\mathrm{CO}_{2}$ exchange $\left(\mathrm{gC} \mathrm{m}^{-2} \mathrm{yr}^{-1}\right)$, (c) $\mathrm{N}_{2}$ fixation $\left(\mathrm{gN} \mathrm{m}^{-2} \mathrm{yr}^{-1}\right)$, (d) denitrification $\left(\mathrm{gN} \mathrm{m}^{-2} \mathrm{yr}^{-1}\right)$ in 2000 and surface concentrations of $(\mathbf{e}) \mathrm{NO}_{3}(\mu \mathrm{M})$ and (f) $\mathrm{Fe}(\mathrm{nM})$ in 2000.

\subsection{Impact on NPP}

Despite an overall reduction of $60 \%$ in aeolian $\mathrm{Fe}$ input, we find little impact upon global NPP by 2100 . At the beginning of our experiments (1860), annual NPP is $35.8 \mathrm{Pg} \mathrm{C} \mathrm{yr}^{-1}$ and declines to 35.3 and $34.6 \mathrm{Pg} \mathrm{C} \mathrm{yr}^{-1}$ by 2000 and 2100 , respectively (Table 1). This represents a decline of only $3.3 \%$ (1.2 Pg C) or $1.8 \%$ (0.7 Pg C) between 1860 and 2100 or 2000 and 2100, respectively (Table 1). As expected, NPP is reduced in the HNLC regions that are impacted by the reduced aeolian Fe input, such as the Atlantic sector of the Southern Ocean (ATL-SO, by 15 to $30 \mathrm{gC} \mathrm{m}^{-2}$ ), the Sub Arctic Pacific (SAPac, by 5 to $15 \mathrm{gC} \mathrm{m}^{-2}$ ) and the Equatorial $\mathrm{Pa}-$ cific (EqPac, by 5 to $30 \mathrm{gC} \mathrm{m}^{-2}$ ) (Figs. 1, 2a, 3a, between 2000 and 2100). Nevertheless, the overall reductions in NPP are only slight (especially in the Sub Arctic Pacific and the Antarctic sector of the Southern Ocean) and suggest that aeolian Fe input is only important in regions directly adjacent to dust sources. This is probably because the continental shelf is the hypothesized to be the principal source of Fe to the mixed layer in the large majority of HNLC waters (Tyrrell et al., 2005; Blain et al., 2007; Aumont et al., 2008).

The spatial re-organization in NPP that follows the reduction in aeolian $\mathrm{Fe}$ input is responsible for the small change in global NPP that results. The decline in ATL-SO NPP (Fig. 3a) reduces the utilization of macronutrients (such as $\mathrm{NO}_{3}$ ) and an excess therefore remains in surface waters (up to $2 \mu \mathrm{M}$ between 2000 and 2100, Fig. 4a). These excess nutrients are now able to enter mode waters (especially in the ATL-SO, Fig. 4d) and fuel additional NPP in the macronu- trient limited low latitudes (Fig. 3a) (Aumont et al., 2003; Sarmiento et al., 2004a; Aumont and Bopp, 2006). A similar mechanism also occurs in the EqPac, where the decline in eastern tropical Pacific (ETP) NPP and $\mathrm{NO}_{3}$ utilization is balanced by elevated NPP in the western tropical Pacific (WTP) (Fig. 3a) as the unused upwelled nutrients flow westward (Dutkiewicz et al., 2005). This highlights the dynamic nature of the global ocean system, whereby changes in local nutrient utilization can have far field ramifications (Sarmiento et al., 2004a; Dutkiewicz et al., 2005; Aumont and Bopp, 2006). Overall, the net effect of this reorganization of NPP is a slight decline in globally integrated NPP (Table 1), despite the greatly reduced dust inputs.

\subsection{Species composition and nutrients}

Despite a small effect on global NPP, reduced aeolian Fe input does cause a decline in diatom abundance in high latitude HNLC waters. In the Southern Ocean, for example, lower aeolian Fe inputs reduce the competitive advantage of diatoms and drive a floristic shift to the smaller nanophytoplankton functional group (by as much as 30\%, Fig. 4d). This is due to the higher affinity for dissolved Fe that is associated with nanophytoplankton, relative to diatoms (Aumont and Bopp, 2006). Overall, the degree of diatom Fe limitation increases by between 10 and over $60 \%$ between 2000 and 2100 , compared to around 5 to $25 \%$ for the nanophytoplankton PFT. As a consequence, the abundance of diatom grazing mesozooplankton also declines, resulting in a more regenerative marine food web. Overall, the Fe-mediated shift in food 
Table 1. The impact of the simulated change in aeolian Fe deposition (Fe Dep, ${\mathrm{Tg} \mathrm{Fe} \mathrm{yr}^{-1} \text { ) on globally integrated NPP (NPP, Pg C yr }}^{-1}$ ), $\mathrm{N}_{2}$ fixation $\left(\mathrm{N}_{2} \mathrm{Fix}, \mathrm{Tg} \mathrm{Nyr}^{-1}\right)$, denitrification (Denitr, $\mathrm{TgNyr}{ }^{-1}$ ), the air-sea $\mathrm{CO} 2$ exchange $\left(\mathrm{FCO}_{2}, \mathrm{PgC} \mathrm{yr}^{-1}\right)$, and export production $\left(\mathrm{Ex} \mathrm{P}, \mathrm{Pg} \mathrm{Cyr}^{-1}\right)$ at three time points. The number in parenthesis is the percentage change relative to a control run, at the same point in time, which includes the change in atmospheric $\mathrm{pCO}_{2}$, but assumes pre industrial (i.e. 1860) dust deposition.

\begin{tabular}{ccccccc}
\hline Year & Fe Dep & NPP & $\mathrm{N}_{2}$ Fix & Denitr & $\mathrm{FCO}_{2}{ }^{\mathrm{a}}$ & $\mathrm{Ex} \mathrm{P}^{\mathrm{b}}$ \\
\hline 1860 & 0.25 & 35.8 & 81.7 & 39.4 & -0.1 & 8.3 \\
2000 & $0.16(-38)$ & $35.3(-1.5)$ & $75.7(-7.4)$ & $36.1(-8.5)$ & $1.9(-5.5)$ & $8.1(-2.1)$ \\
2100 & $0.06(-60)$ & $34.6(-3.3)$ & $67.8(-17.0)$ & $34.4(-12.7)$ & $6.2(-3.4)$ & $7.8(-5.1)$ \\
\hline
\end{tabular}

${ }^{\text {a }}$ For $\mathrm{FCO}_{2}$, a positive value denotes ocean uptake of atmospheric $\mathrm{CO}_{2}$ and a negative percentage change therefore represents a reduction in ocean uptake.

${ }^{\mathrm{b}}$ Export production is defined as the amount of POC passing the $100 \mathrm{~m}$ depth horizon.

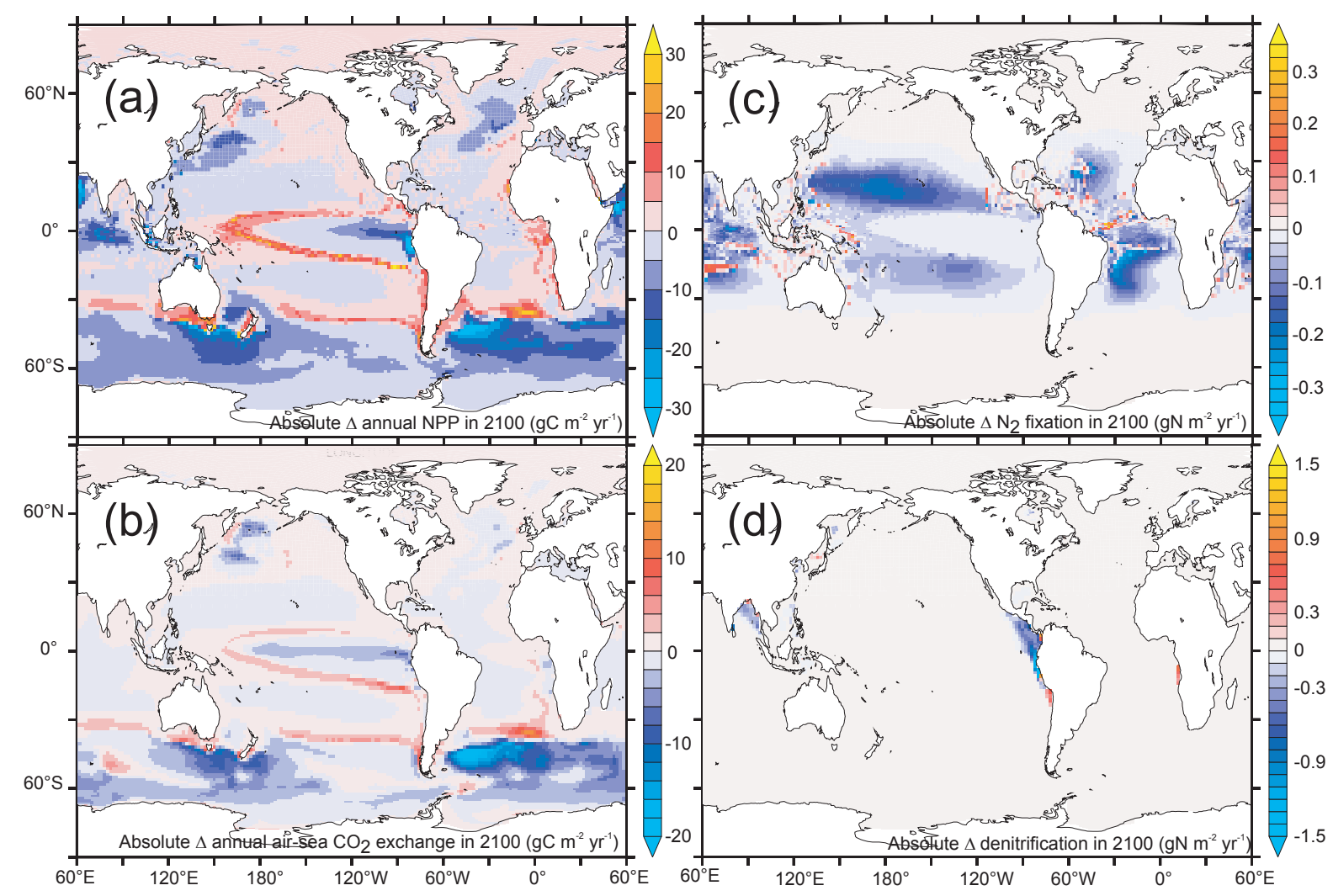

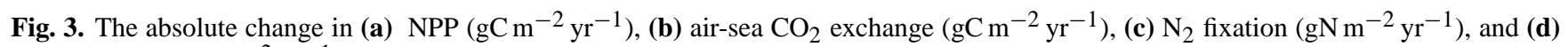
denitrification $\left(\mathrm{gN} \mathrm{m}^{-2} \mathrm{yr}^{-1}\right)$, between 2000 and 2100 .

web structure results in a larger relative decline in $\mathrm{C}$ export, relative to NPP, by $2100(-5.1$ and $-3.3 \%$ for carbon export and NPP, respectively, Table 1).

Only the concentrations of non-limiting nutrients will change greatly by 2100 . As mentioned previously, $\mathrm{NO}_{3}$ concentrations increase in the $\mathrm{Fe}$-limited HNLC regions where aeolian Fe input declines (Figs. 1, 4a, 5). While high residual $\mathrm{NO}_{3}$ concentrations unsurprisingly persist in the Southern Ocean, EqPac, and SAPac, we also predict excess $\mathrm{NO}_{3}$ in North Atlantic under low aeolian Fe deposition conditions (Fig. 4a). Indeed, the spatial extent of diatom Fe limitation increases by 2100 (Fig. 5a and c), thus highlighting the potential importance of atmospheric supply as a source of Fe to this particular region. In the N-STP and tropical Atlantic, N remains the limiting nutrient and prevents any accumulation of residual $\mathrm{NO}_{3}$ (Figs. 4a, 5) despite the increased transport of $\mathrm{NO}_{3}$ from adjacent regions of reduced NPP (Fig. 3a). Similarly, it is only in regions that are not Fe limited that we see 


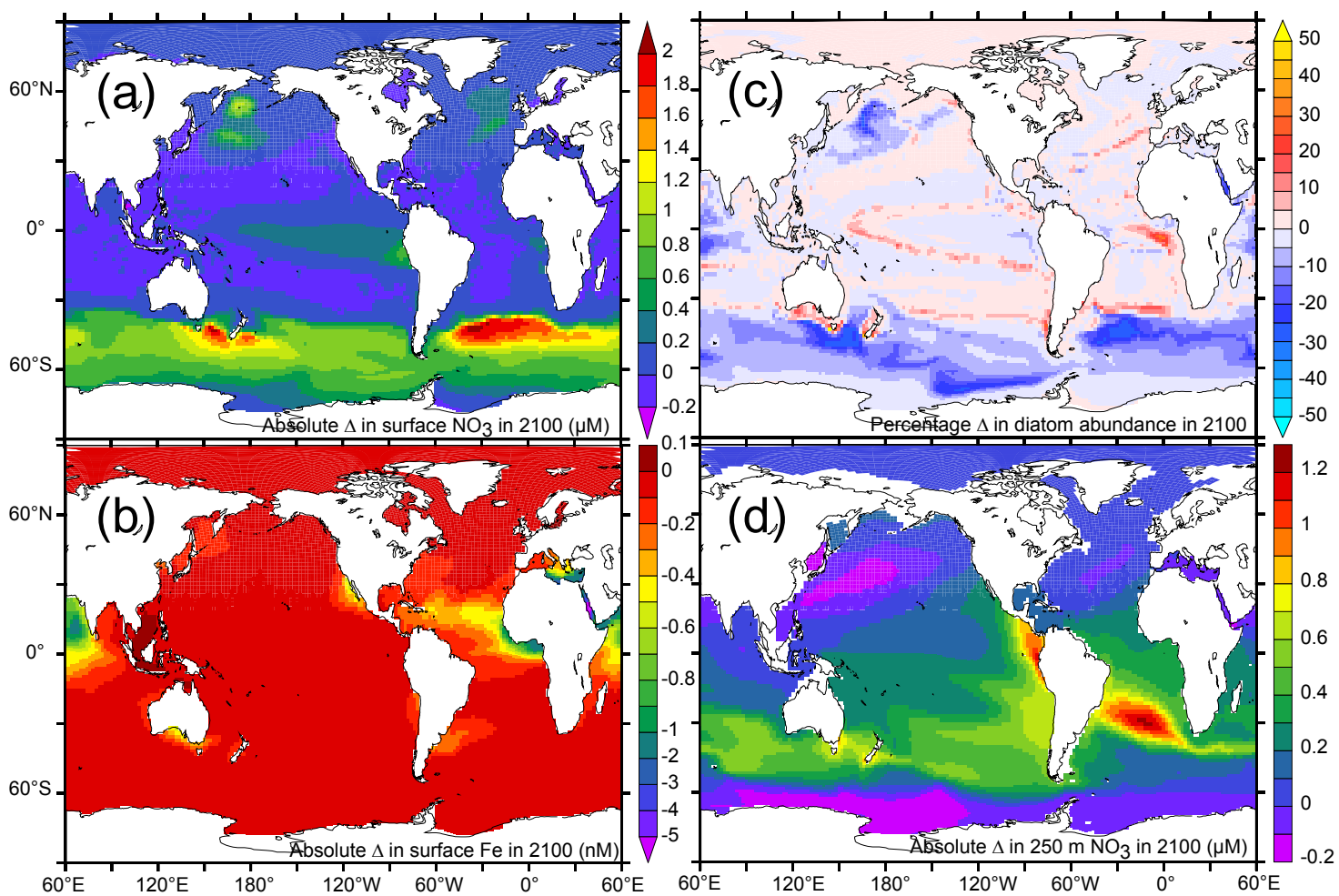

Fig. 4. The change in the annually averaged (a) $\mathrm{NO}_{3}$ at the surface (absolute, $\mu \mathrm{M}$ ), (b) Fe at the surface (absolute, nM), (c) the abundance of diatoms (percentage change in the proportion of total phytoplankton $\mathrm{C}$ associated with diatoms), and (d) $\mathrm{NO}_{3}$ at $250 \mathrm{~m}$ (absolute, $\mu \mathrm{M}$ ), between 2000 and 2100 .

any change in $\mathrm{Fe}$ concentrations by 2100 (Figs. 4b, 5). Although there is less Fe being delivered to the Southern Ocean and the EqPac, in particular, by 2100 (Fig. 1), phytoplankton utilize all available Fe and therefore do not change surface concentrations. That said, there are notable reductions in $\mathrm{Fe}$ concentrations in the northern subtropical Atlantic Ocean, as well as the Indian Ocean; regions of particularly high atmospheric deposition rates (Jickells et al., 2005; Mahowald et al., 2006).

The diagnostic tracer $\mathrm{Si}^{*}\left(\left(\mathrm{Si}(\mathrm{OH})_{4}\right)-\left(\mathrm{NO}_{3}\right)\right)$ was originally proposed by Sarmiento et al. (2004a) and declines with increasing $\mathrm{Fe}$ stress, due to the elevated $\mathrm{Si} / \mathrm{N}$ uptake ratios of Fe limited diatoms (e.g., Takeda, 1998). However, we find that although Fe stress does increase in 2100 (see above), the replacement of diatoms by nanophytoplankton (which have no $\mathrm{Si}(\mathrm{OH})_{4}$ requirement) actually increases $\mathrm{Si}^{*}$ (not shown). Therefore, Fe-mediated changes in phytoplankton species composition (e.g. Fig. 4c), with particular regard to any taxon-specific Si requirements, should be considered when evaluating spatio-temporal changes in $\mathrm{Si}^{*}$. For example, the exhaustion of $\mathrm{Si}(\mathrm{OH})_{4}$ at more southerly latitudes than $\mathrm{NO}_{3}$ in the Southern Ocean (causing negative $\mathrm{Si}^{*}$ ) (Franck et al., 2000; Sarmiento et al., 2004a), might arise from local aeolian inputs of $\mathrm{Fe}$, or the advection of high$\mathrm{Fe}$ subsurface waters from Patagonian shelf sources of $\mathrm{Fe}$
(Fig. 1b). Greater Fe supply would allow diatoms to make up a greater proportion of phytoplankton biomass near dust deposition sites, therefore increasing $\mathrm{Si}(\mathrm{OH})_{4}$ uptake and reducing $\mathrm{Si}^{*}$ (i.e. the inverse of our results).

\subsection{Nitrogen biogeochemistry}

\subsubsection{Integrated rates and spatial distributions}

Annual global $\mathrm{N}_{2}$ fixation is $75 \mathrm{Tg} \mathrm{N} \mathrm{yr}^{-1}$ (in 2000, Table 1), which is towards the lower end of the estimate of $120 \pm 50 \mathrm{Tg} \mathrm{N} \mathrm{yr}^{-1}$ proposed by Gruber (2004) in a recent synthesis. Regarding specific ocean basins, Mahaffey et al. (2005) compiled estimates of Atlantic $\mathrm{N}_{2}$ fixation that are between 15 and $77 \mathrm{Tg} \mathrm{N} \mathrm{yr}^{-1}$, while Pacific $\mathrm{N}_{2}$ fixation rates were 21 to $59 \mathrm{Tg} \mathrm{N} \mathrm{yr}^{-1}$ (Mahaffey et al., 2005 and references therein). We find area-integrated rates are 24.2 and 31.3 Tg N yr${ }^{-1}$ for the Atlantic and Pacific Oceans, respectively during this study (in 2000, Table 2). More recently, a model-based study (Deutsch et al., 2007) concluded that $\mathrm{N}_{2}$ fixation rates in the Pacific may be as much as twice as high as those in the Atlantic and proposed one of the highest global $\mathrm{N}_{2}$ fixation rates (137 $\mathrm{Tg} \mathrm{N} \mathrm{yr}^{-1}$ ). In our model, $\mathrm{N}_{2}$ fixation is of roughly the same order in the Atlantic and the Pacific and is distributed throughout the tropical oceans, apart from the high $\mathrm{NO}_{3}$ EqPac (Fig. 2c). This is a region 

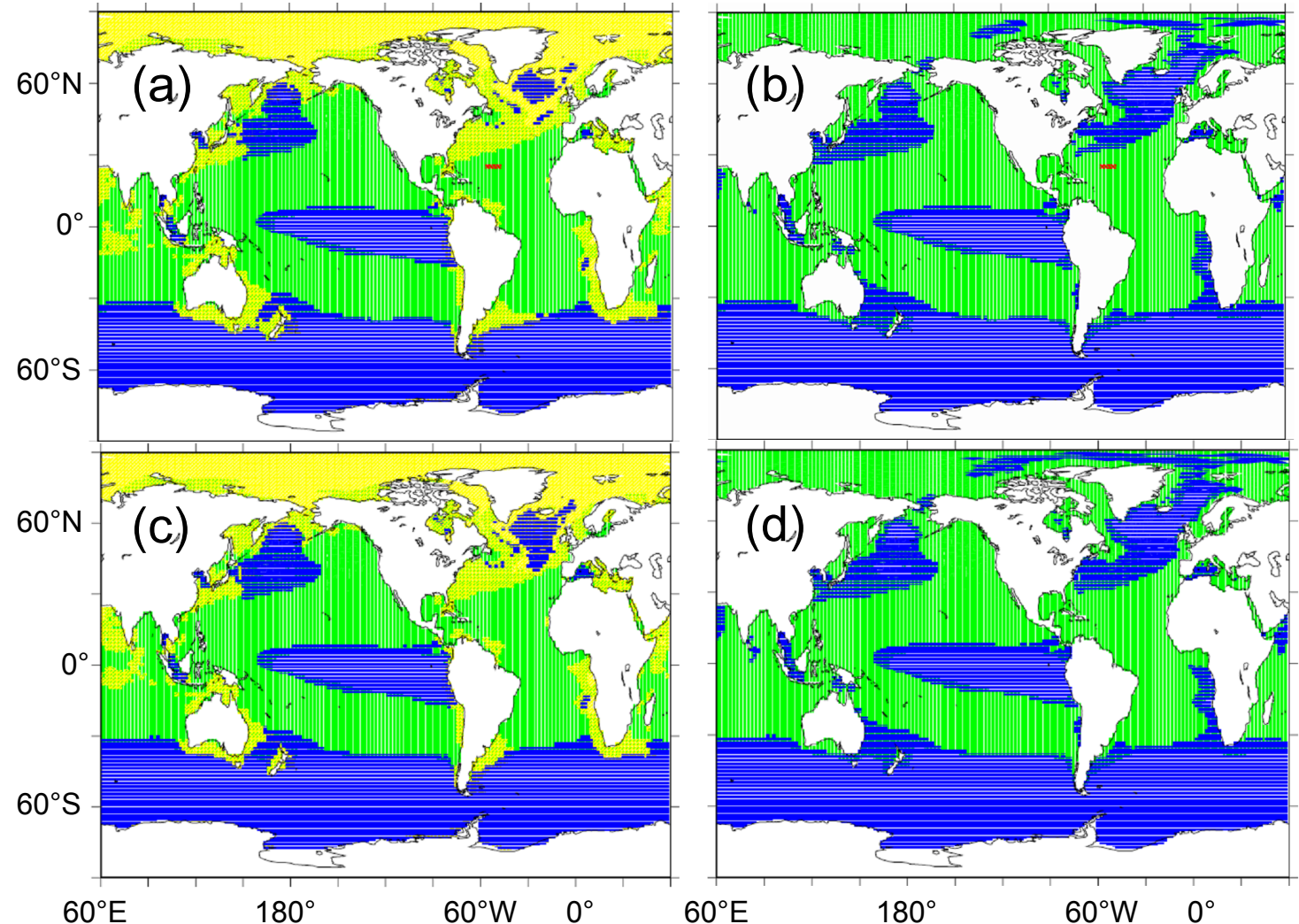

Fig. 5. Maps of nutrient limitation for 2000 and 2100 diatoms (panels (a) and (c), respectively) and nanophytoplankton (panels (b) and (d), respectively). The shading represents thze spatial area where a given nutrient is the most limiting for a minimum of 3 months (green for $\mathrm{NO}_{3}$, red for $\mathrm{PO}_{4}$, yellow for $\mathrm{Si}$, and blue for $\mathrm{Fe}$.)

where Deutsch et al. (2007) predict very high rates of $\mathrm{N}_{2}$ fixation (greater than $200 \mathrm{mmol} \mathrm{N} \mathrm{m}^{-2} \mathrm{yr}^{-1}$ ), despite high concentrations of DIN, and may go someway towards explaining the disparity between our estimates. In the Indian Ocean we obtain $20 \mathrm{Tg} \mathrm{N} \mathrm{yr}^{-1}$ of $\mathrm{N}_{2}$ fixation, but while both geochemical evidence (Gruber and Sarmiento, 1997) and the few measurements available (Capone et al., 1997) would support high rates of $\mathrm{N}_{2}$ fixation, no basin scale estimate exists.

Global denitrification is $36.1 \mathrm{Tg}$ of $\mathrm{N} \mathrm{yr}^{-1}$ (in 2000, Table 1) and is dominated by the ETP region (Table 2, Fig. 2d). This is somewhat below the $65 \pm 20 \mathrm{Tg} \mathrm{N} \mathrm{yr}^{-1}$ proposed by Gruber (2004) for pelagic denitrification and well beneath estimates of up to $150 \mathrm{Tg} \mathrm{N} \mathrm{yr}^{-1}$ (Codispoti et al., 2001). Unfortunately, while we are able to capture the major features of ETP denitrification (Fig. 2d, Table 2), we evidently underestimate Indian Ocean denitrification severely (Table 2). As a result of the high rates of Antarctic bottom water formation near the Antarctic shelf, as well as the relatively high resolution simulations that are needed to accurately capture the complex physics, Indian Ocean deep waters contain too much oxygen in PISCES. Therefore, denitrification rates are retarded in a region that has been estimated to consume over $20 \mathrm{Tg} \mathrm{N}$ per year (Howell et al., 1997), a factor of 5 greater than we find (Table 2). In addition, our model also does not include any sedimentary denitrification, which can be between 180 and $300 \mathrm{Tg} \mathrm{N} \mathrm{yr}^{-1}$ (Codispoti et al., 2001; Gruber, 2004).

Overall, our value for global annual pelagic $\mathrm{N}_{2}$ fixation of $75.7 \mathrm{Tg} \mathrm{N}$ (for 2000, Table 1) is very similar (also in terms of spatial distributions, Fig. 2a) to estimates of 58 to $75 \mathrm{Tg} \mathrm{N} \mathrm{yr}{ }^{-1}$ that are produced by models that contain a prognostic $\mathrm{N}_{2}$ fixing PFT (Moore et al., 2006; Moore and Doney, 2007) and well within the geochemistry-based range of $120 \pm 50 \mathrm{Tg} \mathrm{N} \mathrm{yr}^{-1}$ (Gruber, 2004). As regards denitrification, our model results are low relative to those produced by Moore and Doney (2007) $\left(65 \mathrm{Tg} \mathrm{N} \mathrm{yr}^{-1}\right)$, but within the range of 45 to $85 \mathrm{Tg} \mathrm{N} \mathrm{yr}^{-1}$ proposed by Gruber (2004) (especially considering our aforementioned underestimation in the Indian Ocean). Reconciling model results with the high end estimates of water column denitrification of up to $150 \mathrm{Tg} \mathrm{N} \mathrm{yr}^{-1}$ (Codispoti et al., 2001; Galloway et al., 2004) remains a challenge for global oceanbiogeochemistry models.

\subsubsection{Changes in $\mathrm{N}_{2}$ fixation with dust}

$\mathrm{N}_{2}$ fixation responds much more dramatically to changes in aeolian Fe deposition than NPP. Globally, $\mathrm{N}_{2}$ fixation de- 
Table 2. Integrated annual rates $\left(\mathrm{Tg} \mathrm{N} \mathrm{yr}^{-1}\right)$ of $\mathrm{N}_{2}$ fixation and denitrification, as a function of year and ocean basin. The number in parenthesis is the percentage change relative to a control run, at the same point in time, which includes the change in atmospheric $\mathrm{pCO}_{2}$, but assumes pre industrial (i.e. 1860) dust deposition. See Table 1 for the globally integrated rates.

\begin{tabular}{lllllll}
\hline & \multicolumn{3}{c}{$\mathrm{N}_{2}$ Fixation $\left(\mathrm{Tg} \mathrm{N} \mathrm{yr}^{-1}\right)$} & \multicolumn{3}{c}{ Denitrification $\left(\mathrm{Tg} \mathrm{N} \mathrm{yr}^{-1}\right)$} \\
\hline \multirow{2}{*}{1860} & Atlantic & Pacific & Indian & Atlantic & Pacific & Indian \\
2000 & 25.2 & 35.2 & 21.0 & 2.0 & 33.4 & 4.2 \\
& 24.2 & 31.3 & 20.0 & 2.1 & 29.9 & 4.1 \\
2100 & $(-4.1)$ & $(-11.2)$ & $(-5.1)$ & $(+7.9)$ & $(-10.5)$ & $(-2.3)$ \\
& 22.2 & 26.8 & 18.6 & 2.2 & 28.5 & 3.8 \\
& $(-12.1)$ & $(-23.9)$ & $(-11.6)$ & $(+13.1)$ & $(-14.7)$ & $(-10.7)$ \\
\hline
\end{tabular}

clines by $17 \%$ (or $14 \mathrm{Tg} \mathrm{N}$ ) to approximately $67 \mathrm{Tg} \mathrm{N} \mathrm{yr}^{-1}$ by the end of our 240 year simulation (in 2100, Table 1). The majority of this reduction is due to changes in the Pacific Ocean basin, wherein $\mathrm{N}_{2}$ fixation declines by almost $25 \%$ (Table 2 ). In contrast, $\mathrm{N}_{2}$ fixation declined by slightly more than $10 \%$ in the Atlantic and Indian Oceans. Overall, changes in aeolian $\mathrm{Fe}$ input have a far greater impact on $\mathrm{N}_{2}$ fixation (by as much as $25 \%$ ) than NPP or C export (3 to $5 \%$, Table 1).

$\mathrm{N}_{2}$ fixation reacts both directly and indirectly to the reduced aeolian Fe inputs. The largest absolute decline in $\mathrm{N}_{2}$ fixation occurs in the southern subtropical Atlantic (Fig. 3c) and is a result of both reduced aeolian input of $\mathrm{Fe}$ (Fig. 1), as well as additional $\mathrm{NO}_{3}$ that results from the Fe-mediated decline in ATL-SO NPP (Figs. 3a, 4a). Moreover, the large area of reduced absolute $\mathrm{N}_{2}$ fixation in the N-STP gyre (Fig. 3c) is also a consequence of both the additional $\mathrm{NO}_{3}$ that is transported from the region of reduced NPP in the EqPac (Figs. 3a, 4a), as well as reduced Fe input (Fig. 1). Indeed, $\mathrm{N}_{2}$ fixation in the N-STP gyre will be highly sensitive to any Fe-mediated changes in DIN utilization in the directly adjacent HNLC regions such as the EqPac and SAPac (Figs. 3a and $4 \mathrm{a})$, as well as local changes in $\mathrm{Fe}$ inputs.

Moore et al. (2006) suggest that annual $\mathrm{N}_{2}$ fixation would decline by almost $40 \mathrm{Tg} \mathrm{N}$ under an identical reduction in dust, far greater than our reduction of $<10 \mathrm{Tg} \mathrm{N}$ (Table 1). This is because Moore et al. (2006) conducted 40 year simulations using the future dust deposition field, wherein the impact of the reduced dust input will be exaggerated, relative to our incremental decline in dust deposition from 1860 to 2100. Indeed, the reduction in annual $\mathrm{N}_{2}$ fixation of 10 to $20 \mathrm{Tg} \mathrm{N}$ from the first 2 years of Moore et al. (2006) is more in line with our results.

\subsubsection{Changes in denitrification with dust}

Denitrification also exhibits a strong response to the reduced atmospheric Fe inputs simulated in this study. This is due to the Fe mediated changes in $\mathrm{C}$ export, which modify the amount of $\mathrm{O}_{2}$ consumed during remineralization and consequentially, the amount of denitrification that occurs. In the Pacific Ocean, the reduction in ETP NPP (Fig. 3a), results in greater subsurface $\mathrm{O}_{2}$ concentrations and denitrification declines accordingly (by 24\%, Table 2). On the other hand, the increase in low latitude NPP is responsible for the very slight absolute increase in Atlantic Ocean denitrification (Fig. 3a and $\mathrm{d}$, Table 2). The decline in ETP denitrification results in additional subsurface $\mathrm{NO}_{3}$ (Fig. 4d), which will eventually enter surface waters and will reduce the area over which $\mathrm{N}_{2}$ fixation is selected for. While $\mathrm{N}_{2}$ fixation can be directly controlled by the degree of Fe limitation, denitrification responds to the change in export production (and thus $\mathrm{O}_{2}$ consumption) that results from the impact of Fe (or any other resource) on NPP (processes "I", "J", "K", and "F" in Fig. 6).

\subsubsection{The interplay between $\mathrm{N}_{2}$ fixation and denitrification}

At the beginning of our experiments the imbalance between pelagic $\mathrm{N}_{2}$ fixation and denitrification amounts to excess of 42.3 Tg N. As mentioned previously, this most likely results from our underestimation of Indian Ocean denitrification and the absence of any benthic DIN consumption. For comparison, the recent synthesis of Gruber (2004) includes an imbalance of $65 \mathrm{Tg} \mathrm{N}$ between $\mathrm{N}_{2}$ fixation and denitrification. Over the course of our experiment, the degree of imbalance declines by around $9 \mathrm{Tg} \mathrm{N}$ (to $33.4 \mathrm{Tg} \mathrm{N}$, Table 1) and results from the rapid response of $\mathrm{N}_{2}$ fixation to the surface water consequences of the reduction in aeolian Fe input (on both Fe and DIN concentrations).

Denitrification remains a relatively constant fraction of $\mathrm{N}_{2}$ fixation by the end of our simulations (Table 2), in accord with hypotheses of a homeostatic DIN inventory. This is especially so in the Pacific Ocean, where $\mathrm{N}_{2}$ fixation and denitrification are tightly coupled over the duration of our exper- 


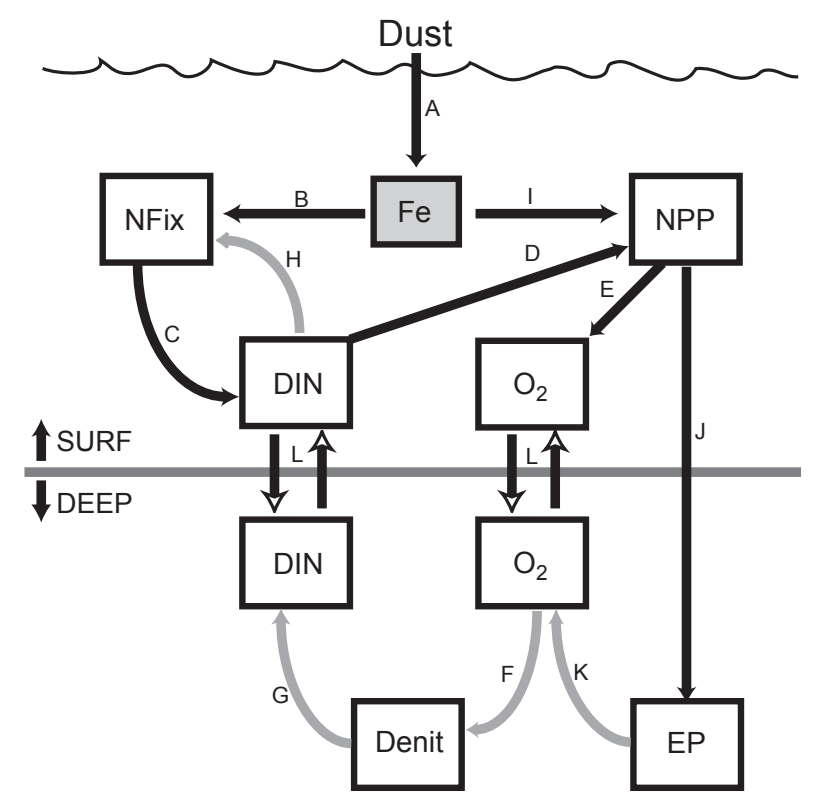

Fig. 6. A schematic to illustrate the impact of a change in Fe deposition on, and the feedbacks between, NPP, export production (EP), $\mathrm{N}_{2}$ fixation (Nfix), and denitrification (Denit). Positive and negative feedbacks are represented by black and gray arrows, respectively. The deposition of dust alters the dissolved Fe concentration (process (a), which then increases $\mathrm{N}_{2}$ fixation (b)and, by consequence, surface DIN concentrations (assumed here to be $\mathrm{NO}_{3}+\mathrm{NH}_{4}$ ) (c). Elevated DIN concentrations can increase NPP (d) and oxygen concentrations (d). Once transported to the subsurface (l), greater oxygen concentrations will retard denitrification (f) and therefore increase subsurface DIN (g). When this DIN is mixed into surface waters (l), it will reduce $\mathrm{N}_{2}$ fixation (h). Alternatively, additional $\mathrm{Fe}$ can also stimulate NPP (i), increasing export production (j), which will also reduce subsurface oxygen via remineralization (k), which will stimulate denitrification (f).

iment (240 years, Table 2 ). This is probably due to the geographic proximity of regions of $\mathrm{N}_{2}$ fixation and denitrification in the Pacific, as well as the increased deep-water ventilation over ETP denitrification sites (Deutsch et al., 2007). In contrast, Moore and Doney (2007) used an alternative experimental design (varying nitrogen cycle parameters) to suggest $\mathrm{N}_{2}$ fixation and denitrification feedbacks were 'muted' in the Pacific Ocean. For example, simulated changes in $\mathrm{N}_{2}$ fixation yielded a lesser change in denitrification (and vice-versa) than was seen in other ocean basins (Moore and Doney, 2007). In our study, $\mathrm{N}_{2}$ fixation and denitrification are strongly coupled in Pacific (Table 2) and the high rates of denitrification in the ETP are mostly supported by the high rates of NPP (e.g., Fig. 2a), and thus C export, that arise from the local upwelling of nutrients. We find that denitrification reacts to the impact of Fe on ETP NPP, rather than $\mathrm{N}_{2}$ fixation (as noted by Moore and Doney, 2007), but that $\mathrm{N}_{2}$ fixation responds to changes in DIN utilization in the ETP, as well as to
Fe. Longer simulations will be necessary in order to assess the complete impact of any change in subsurface DIN (driven by export production and denitrification) on $\mathrm{N}_{2}$ fixation that will be mediated by ocean circulation (as hypothesized by Deutsch et al., 2007).

The impact of $\mathrm{N}_{2}$ fixation and denitrification on DIN concentrations are segregated with respect to depth (Fig. 6). Denitrification responds to the subsurface consequences of the reduction in aeolian $\mathrm{Fe}$ input on $\mathrm{C}$ export and $\mathrm{O}_{2}$ consumption (processes " $K$ " and " $F$ " in Fig. 6), by either stimulating $\mathrm{N}_{2}$ fixation or NPP (processes "B" and "I" in Fig. 6). Therefore, the degree of deep-water ventilation will control the efficiency with which denitrification can negatively feedback onto $\mathrm{N}_{2}$ fixation (via DIN concentrations, processes "G", "L", and "C" in Fig. 6). Reduced ventilation will also reduce vertical nutrient supply (process "L" in Fig. 6), as well as reducing subsurface $\mathrm{O}_{2}$ concentrations, which may further reduce vertical DIN supply (via greater consumption during denitrification (processes "F" and "G" in Fig. 6). Nevertheless, any decline in vertical nutrient supply would reduce surface NPP, $\mathrm{C}$ export and subsurface $\mathrm{O}_{2}$ consumption, thereby resulting in reduced denitrification (Fig. 6). Overall, the inter play between Fe fuelled NPP and $\mathrm{N}_{2}$ fixation and the subsequent impact on DIN, C export, as well as remineralization and denitrification in subsurface waters becomes much more complex when changes in exogenous nutrient inputs are accompanied by changes in physical mixing (Fig. 6). Additional field measurements of the temporal changes in the processes and pools represented in Fig. 6, as well the degree of ocean ventilation, would greatly assist future investigations.

Overall, our results suggest that it is unlikely that $\mathrm{Fe}$ can significantly unbalance the oceanic $\mathrm{N}$ cycle (Moore and Doney, 2007), especially over long timescales. While the decline in aeolian $\mathrm{Fe}$ deposition does reduce $\mathrm{N}_{2}$ fixation, it is accompanied by an oxygen mediated decline in the amount of denitrification (Tables 1 and 2). Moreover, besides the direct requirement of $\mathrm{N}_{2}$ fixation for $\mathrm{Fe}$, it is also important to consider that $\mathrm{Fe}$ will influence the amount of NPP, and thus DIN utilization, that occurs in the HNLC regions (Figs. 4a and 5). In this sense, anything that changes the degree of EqPac DIN utilization (not only $\mathrm{Fe}$ ) has the potential to feedback onto both surface $\mathrm{N}_{2}$ fixation and subsurface denitrification (processes "D" and "H", as well as "D", "J", "K", "F" and "G" in Fig. 6). This suggests that the ocean DIN inventory would be relatively insensitive to any increases in aeolian $\mathrm{Fe}$ input that may have occurred during the geologic past (e.g., during the last glaciation, LGM). That said, if increased dust deposition was also accompanied by a decline in ETP ocean ventilation (i.e. altering the strength of process "L" in Fig. 6), then the efficiency of the denitrification- $\mathrm{N}_{2}$ fixation feedback can potentially become more complex (see above). 


\subsection{Air-sea $\mathrm{CO}_{2}$ exchange}

Ocean uptake of atmospheric $\mathrm{CO}_{2}\left(\mathrm{FCO}_{2}\right)$ is $1.9 \mathrm{Pg} \mathrm{C} \mathrm{yr}^{-1}$ in 2000 (Table 1, Fig. 2b) and compares well with current estimates of approximately $2 \mathrm{Pg} \mathrm{C} \mathrm{yr}^{-1}$ (Le Quéré et al., 2003). The 38\% decline in dust deposition between the PI period and present day reduces $\mathrm{FCO}_{2}$ by $5.5 \%$ (or $0.1 \mathrm{Pg} \mathrm{C}$ ), relative to the impact of the $80 \mu \mathrm{atm}$ rise in atmospheric $\mathrm{pCO}_{2}$ (Table 1). However, by 2100 the $470 \mu$ atm increase in atmospheric $\mathrm{pCO}_{2}$ is predominantly responsible for the change in the global ocean $\mathrm{C}$ sink (to $6.2 \mathrm{Pg} \mathrm{C} \mathrm{yr}^{-1}$ ) and dust decreases ocean uptake by only $3.4 \%$ (or $0.22 \mathrm{Pg} \mathrm{C}$, Table 1 ). Cumulatively, the ocean takes up $22.8 \mathrm{Pg}$ less $\mathrm{C}$ between 1860 and 2100 , despite an $60 \%$ reduction in aeolian Fe input (or $4 \%$ of the $529.8 \mathrm{Pg}$ of $\mathrm{C}$ taken up by the ocean assuming PI dust for 240 years).

As seen for NPP, the change in dust deposition results in a spatial reorganization in $\mathrm{FCO}_{2}$ (Fig. 3b). The degree of uptake of atmospheric $\mathrm{CO}_{2}$ in the ATL-SO (Fig. 2b) is retarded and shifted to lower latitudes (Fig. 3b). Since higher temperatures and lower wind speeds characterize the tropical south Atlantic, gas exchange is reduced and $\mathrm{FCO}_{2}$ declines more than NPP $\left(-5.5 \%\right.$ and $-1.5 \%$ for $\mathrm{FCO}_{2}$ and NPP, respectively, between the PI and present, Table 1). This disparity is all but eliminated by 2100 , by which time the rise in atmospheric $\mathrm{pCO}_{2}$ is the principal control on $\mathrm{FCO}_{2}$ and the reduction in $\mathrm{FCO}_{2}$ is only $0.1 \%$ greater than for NPP (Table 1). The decrease in $\mathrm{EqPac}^{\mathrm{FCO}} 2$ by 2100 is due to an increase in the degree of outgassing (as NPP declines, Fig. 3a) and is partly balanced by increased ocean uptake in the WTP (Figs. 2b and $3 b$ ).

Recent studies have suggested a large reduction in the airsea $\mathrm{CO}_{2}$ flux (Moore et al., 2006) and a dramatic increase in atmospheric $\mathrm{pCO}_{2}$ concentrations (Parekh et al., 2006) might result from a marked decline in oceanic dust deposition. In contrast, our results indicate that the impact of a massive decline in dust on air-sea $\mathrm{CO}_{2}$ fluxes is much lower and is, at most, on the order of 3 to $5 \%$ (Table 1). Moore et al. (2006) found that the ocean uptake of $\mathrm{CO}_{2}$ de-

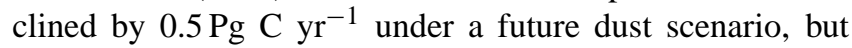
kept atmospheric $\mathrm{pCO}_{2}$ at PI levels $(\sim 280 \mu \mathrm{atm})$. Given that atmospheric $\mathrm{pCO}_{2}$ is projected to increase by as much as $470 \mu$ atm by 2100 , it is difficult to compare to the results of our study, which includes the observed and predicted change in atmospheric $\mathrm{pCO}_{2}$ between 1860 and 2100 (see Methods). Although we did not compute the impact of ocean $\mathrm{CO}_{2}$ fluxes on atmospheric $\mathrm{pCO}_{2}$ (instead this was used as a model forcing), it is clear that the impact of the reduced dust deposition will be far lower than the increase of up to $180 \mu$ atm from Parekh et al. (2006) and would be closer to that of $3 \mu \mathrm{atm}$ from Bopp et al. (2003). In a more recent study, phytoplankton biomass in PISCES was found to be highly insensitive to variability in atmospheric deposition of $\mathrm{Fe}$ (Aumont et al., 2008), mostly because of the explicit representation (Aumont and Bopp, 2006) of the high Fe flux that arises from continental shelves (Elrod et al., 2004; Tyrrell et al., 2005; Lam et al., 2006; Blain et al., 2007). Coarse resolution ocean-biogeochemistry models are often unable to represent the continental shelves and the absence of any sediment Fe source (Dutkiewicz et al., 2005; Parekh et al., 2006) will obviously increase the sensitivity of such models to any changes in aeolian input.

\section{Perspectives}

Our study only addresses the impacts of a change in dust deposition and atmospheric $\mathrm{pCO}_{2}$ on ocean biogeochemistry. In reality, it is highly likely that changes in ocean circulation, such as increased surface stratification (e.g., Sarmiento et al., 2004b), will accompany any possible change in dust deposition. Greater stratification will impact the vertical supply of nutrients to surface waters, which might hamper the growth of large PFTs, such as diatoms (Bopp et al., 2005). Changing the degree of ocean ventilation also has the potential to change subsurface $\mathrm{O}_{2}$ concentrations, which would impact denitrification rates. Moreover, reduced ventilation might also reduce the efficiency of the denitrification $-\mathrm{N}_{2}$ fixation negative feedback (process "L" in Fig. 6), especially in the ETP. To that end, longer simulations would be required to adequately address the impact of changes in deep nutrient inventories (driven by export production and denitrification) or longer term changes in aeolian Fe deposition (e.g. during the LGM) on surface biogeochemistry.

The low solubility of dust borne $\mathrm{Fe}$ in this study does not drive the weak response of ocean biogeochemistry to reduced aeolian deposition. The bias in annually averaged $\mathrm{dFe}$ concentrations (between PISCES and observations) is heterogeneous in surface waters (with a mean of $-0.12 \mathrm{nM}$ ) and suggests PISCES actually overestimates $\mathrm{dFe}$ in regions of high dust deposition (e.g. the tropical Atlantic and western Indian Oceans), despite our low solubility. In subsurface waters $(100$ to $300 \mathrm{~m})$, we find no systematic overestimation of $\mathrm{dFe}$ concentrations (the mean bias is $+0.05 \mathrm{nM}$ ) that could dampen the response of PISCES to variability in dust deposition as suggested by Moore and Braucher (2007). In addition, we note that PISCES does also include subsurface dissolution of dust particles that did not dissolve in surface waters (Aumont and Bopp, 2006). In reality, the solubility of dust $\mathrm{Fe}$ is likely low in regions that experience high deposition rates of large particles and vice versa (e.g. Baker and Jickells, 2006), as well as varying as a function of atmospheric transit time (Jickells and Spokes, 2001), aerosol type (Sedwick et al., 2007) and the mode of deposition (wet or dry, Jickells and Spokes, 2001). The wide range in direct estimates of Fe solubility (from $<1$ to $90 \%$ ), reflect the relative contributions of these processes in different ocean regions, as well as differences in measurement protocols (see: Sedwick et al., 2007 for a summary and associated references). For example, Sedwick et al. (2007) report that Saharan aerosols 
had high dust loads, but very low solubility $(0.44 \%)$. On the other hand, anthropogenic aerosols from North America had a 100-fold lower concentration, but a 40-fold higher solubility (Sedwick et al., 2007). Accounting for the variable solubility of dust borne Fe in global models is a necessary next step that may aid in improving modeled dFe distributions. While dust borne Fe may be more soluble in regions that experience low rates of deposition, we do not feel that this would greatly impact our results, since these regions show little change by 2100 . In addition, the weak response of NPP and $\mathrm{FCO}_{2}$ to a reduction in dust deposition results from compensatory biogeochemical processes that arise in adjacent ocean regions rather than an underestimation of the direct dust effect. Indeed, we find the local response can be large in those regions that are directly impacted by changes in dust deposition (Figs. 3 and 4).

Unsurprisingly, Moore and Braucher (2007) found a greater effect on export production and $\mathrm{N}_{2}$ fixation (18 and $48 \%$, respectively) during a 200 year simulation that assumed an instantaneous elimination of the aeolian Fe source. Despite the far greater degree of change in aeolian Fe deposition, the greater impact of dust on $\mathrm{N}_{2}$ fixation than carbon export is in accord with this study (Table 1). However, the steady state role of aeolian Fe in controlling ocean biogeochemistry requires simulations longer than 200 years in order to adequately represent the contribution of non local processes to the response of NPP, carbon export, $\mathrm{N}_{2}$ fixation and atmospheric $\mathrm{CO}_{2}$. These would include the impact of changes in NPP on nutrient redistribution by mode waters.

Recent research has demonstrated an enhancement of $\mathrm{N}_{2}$ fixation rates under higher $\mathrm{CO}_{2}$ concentrations (Hutchins et al., 2007; Barcelos e Ramos et al., 2007), which might offset any dust-mediated decline in $\mathrm{N}_{2}$ fixation. As an initial calculation, we use our modeled spatial increase in $\mathrm{CO}_{2}(\mathrm{aq})$ between 2000 and 2100, alongside a Michaelis-Menten fit to the proportional increase in $\mathrm{N}_{2}$ fixation per unit change in $\mathrm{pCO}_{2}$ from Hutchins et al. (2007), to suggest that global $\mathrm{N}_{2}$ fixation could be enhanced by $22 \mathrm{Tg} \mathrm{N}$ (or 30\%) by 2100 (relative to 2000); more than compensating for the dustmediated decline of $8 \mathrm{Tg} \mathrm{N}$ (Table 1). However, this upper bound estimate assumes that $\mathrm{N}_{2}$ fixation will simply increase with $\mathrm{CO}_{2}(\mathrm{aq})$, while in reality, concentrations of DIN, $\mathrm{Fe}$, and $\mathrm{PO}_{4}$ also exert a strong control. Therefore, any $\mathrm{CO}_{2}$ enhancement would be unlikely to realize the complete $22 \mathrm{Tg} \mathrm{N}$ (or $30 \%$ ) by 2100 . Nevertheless, the $\mathrm{CO}_{2}$ effect on $\mathrm{N}_{2}$ fixation merits further investigation, especially as anthropogenic $\mathrm{CO}_{2}$ is accumulating in the poorly ventilated subtropical gyres (Sabine et al., 2004) that are frequented by $\mathrm{N}_{2}$ fixing phytoplankton (e.g., Mahaffey et al., 2005).

The sensitivity of individual global ocean biogeochemistry models to changes in aeolian iron input will be dependent on the model specific importance of atmospheric deposition, relative to other sources of Fe. The significance of aeolian Fe inputs to global ocean biogeochemistry depends on whether a given model also represents continental shelf inputs of $\mathrm{Fe}$ (low sensitivity to dust), or relies solely on dust as an external source (high sensitivity to dust). Although current global models do not address the observed spatial variability in the solubility of dust-bound Fe, including (or increasing the importance of) the continental shelf Fe inputs does permit a more accurate representation of the elevated phytoplankton biomass and Fe concentrations typical of these regions (Aumont and Bopp, 2006). Notwithstanding, observational estimates of sedimentary Fe fluxes, as well as their geographic variability and the bioavailability of the Fe supplied, remain very limited (but see: Elrod et al., 2004; Lam et al., 2006; Blain et al., 2007) and require further investigation. In particular, research should focus on the spatial variability in sediment Fe fluxes, as well as the solubility and bioavailability of the Fe supplied.

\section{Conclusions}

Despite enforcing a climatically realistic dramatic reduction in the ocean deposition of aerosol Fe, we find that global NPP and $\mathrm{FCO}_{2}$ only decline by around $3 \%$. This is due to the spatial redistribution of NPP that accompanies a decline in aeolian Fe input, as well as the lesser importance of aeolian Fe sources relative to continental shelf supply in PISCES. Locally, dust deposition does have a role in sustaining diatom biomass in the ATL-SO and could therefore be important in controlling the relative utilization of $\mathrm{NO}_{3}$ and $\mathrm{Si}(\mathrm{OH})_{4}$ and the associated marine food web. $\mathrm{N}_{2}$ fixation declines by $17 \%$ in response to both the reduction in Fe supply, as well as the increased DIN concentrations that result from reduced nutrient utilization in dust impacted HNLC regions. Nevertheless, concomitant declines in denitrification stabilize the ocean DIN inventory (especially in the Pacific Ocean) and the excess $\mathrm{NO}_{3}$ that arises from reduced bacterial consumption can act as a negative feedback on $\mathrm{N}_{2}$ fixation. The denitrification $-\mathrm{N}_{2}$ fixation feedback is controlled by changes in nutrients and NPP/carbon export, and its efficiency depends on the degree and timescales of deep-water ventilation above denitrification sites (summarized in Fig. 6). While the enhancement of $\mathrm{N}_{2}$ fixation by elevated $\mathrm{CO}_{2}$ concentrations is not explicitly modeled, we estimate that this process might have the potential to go some of the way towards compensating for any dust mediated decline. The change in air-sea $\mathrm{CO}_{2}$ exchange between 1860 and 2100 is predominantly controlled by the change in atmospheric $\mathrm{pCO}_{2}$ and the decline in dust deposition reduces cumulative uptake (over the 240 year study period) by only $22.8 \mathrm{Pg} \mathrm{C}$, or $4 \%$. The impact of future changes in dust deposition, as well as other changes in climate, on ocean biogeochemical cycles should utilize a variety of global ocean biogeochemical models in order to minimize model-specific conclusions.

Acknowledgements. We thank N. Mahowald (NCAR) for providing us with the dust deposition fields. This manuscript also benefited from insightful discussions with S. Dutkiewicz (MIT) and 
B. Schneider (LSCE), as well as peer reviews by one anonymous reviewer and J. K. Moore. Funding was provided by ANR/GOBAC and all simulations were performed at the French National computing center IDRIS. This is LSCE contribution number $\mathrm{xx}$.

Edited by: T. W. Lyons

\section{References}

Aumont, O., Maier-Reimer, E., Blain, S., and Monfray, P.: An ecosystem model of the global ocean including $\mathrm{Fe}, \mathrm{Si}, \mathrm{P}$ co-limitations, Global Biogeochem. Cy., 17, doi.:10.1029/2001GB001745, 2003.

Aumont, O. and Bopp, L.: Globalizing results from ocean in situ iron fertilization studies, Global Biogeochem. Cy., 20, GB2017, doi:10.1029/2005GB002591, 2006.

Aumont, O., Bopp, L., and Schulz, M.: What does temporal variability in aeolian dust deposition contribute to sea-surface iron and chlorophyll distributions?, Geophys. Res. Lett., in press, 2008.

de Baar, H. J. W., Boyd,P. W., Coale, K. H., et al.: Synthesis of iron fertilization experiments: From the iron age in the age of enlightenment, J. Geophys. Res., 110, C09S16, doi:10.1029/2004JC002601, 2005.

Baker, A. R. and Jickells, T. D.: Mineral particle size as a control on aerosol iron solubility, Geophys. Res. Lett., 33, L17608, doi:10.1029/2006GL026557, 2006.

Barcelos e Ramos, J., Biswas, J. H., Schulz, K. G. LaRoche, J., and Riebesell, U.: Effect of rising atmospheric carbon dioxide on the marine nitrogen fixer Trichodesmium, Global. Biogeochem. Cy., 21, GB2028, doi:10.1029/2006GB002898, 2007.

Blain, S., Queguiner, B., Armand, L., et al.: Effect of natural iron fertilization on carbon sequestration in the Southern Ocean, Nature, 446, 1070-U1, 2007.

Bopp, L., Aumont, O., Cadule, P., Alvain, S., and Gehlen, M.: Response of diatoms distribution to global warming and potential implications: A global model study, Geophys. Res. Lett., 32, L19606, doi:10.1029/2005GL023653, 2005.

Bopp, L., Kohlfield, K. E., Le Quere, C., and Aumont, O.: Dust impact on marine biota and atmospheric $\mathrm{CO}_{2}$ during glacial periods, Paleoceanography, 18, doi:10.1029/2002PA000810, 2003.

Boyd, P. W., Watson, A. J., Law, C. S., Abraham, E. R., Trull, T., Murdoch, R., Bakker, D. C. E., Bowie, A. R., Buesseler, K. O., Chang, H., and Charette, M.: A mesoscale phytoplankton bloom in the polar Southern Ocean stimulated by iron fertilization, Nature, 407, 695-702, 2000.

Boyd, P. W., Law, C. S., Wong, C. S., et al.: The decline and fate of an iron-induced phytoplankton bloom, Nature, 428, 549-553, 2004.

Capone, D. G., Zehr, J. P., Paerl, H. W., Bergman, B., and Carpenter, E.: Trichodesmium, a globally significant marine cyanobacterium, Science, 276, 1221-1229, 1997.

Coale, K. H., Johnson, K. S., Fitzwater, S. E., et al.: A massive phytoplankton bloom induced by an ecosystem-scale iron fertilization experiment in the equatorial Pacific Ocean, Nature, 383, 495-501, 1996.

Codispoti, L., Brandes, J. A., Christensen, J. P., et al.: The oceanic fixed nitrogen and nitrous oxide budgets: Moving targets as we enter the anthropocene?, Sci. Mar., 65, 85-105, 2001.
Codispoti, L. A.: An oceanic fixed nitrogen sink exceeding $400 \mathrm{Tg} \mathrm{N} \mathrm{a}^{-1}$ vs the concept of homeostasis in the fixed-nitrogen inventory, Biogeosciences, 4, 233-253, 2007, http://www.biogeosciences.net/4/233/2007/.

Deutsch, C., Sarmiento, J. L., Sigman, D. M., Gruber, N., and Dunne, J. P.: Spatial coupling of nitrogen inputs and losses in the ocean, Nature, 445, (7124), 163-167, 2007.

Duce, R. A., Liss, P. S., Merrill, J. T., et al.: The atmospheric input of trace species to the world ocean, Global Biogeochem. Сy., 5, 293-259, 1991.

Dutkiewicz, S., Follows, M. J., and Parekh, P.: Interactions of the iron and phosphorous cycles: A three dimensional model study, Global Biogeochem., Cy., 19, GB1021, doi:10.1029/2004GB002342, 2005.

Elrod, V. A., Berelson, W. M., Coale, K. H., and Johnson, K. S.: The flux of iron from continental shelf sediments: A missing source for global budgets, Geophys. Res. Lett., 31, L12307, doi:10.1029/2004GL020216, 2004.

Falkowski, P. G.: Evolution of the nitrogen cycle and its influence on the biological sequestration of $\mathrm{CO}_{2}$ in the ocean, Nature, 387, 272-275, 1997.

Falkowski, P. G., Barber, R. T., and Smetacek, V.: Biogeochemical controls and feedbacks on ocean primary production, Science, 281, 200-206, 1998.

Franck, V. M., Brzezinski, M. A., Coale, K. H., and Nelson, D. M.: Iron and silicic acid concentrations regulate Si uptake north and south of the Polar Frontal Zone in the Pacific Sector of the Southern Ocean, Deep Sea Res., Part II, 47, 3315-3338, 2000.

Galloway, J. N., Dentener, F. J., Capone, D. G, et al.: Nitrogen cycles: past, present and future, Biogeochemistry, 70, 153-226, 2004.

Ginoux, P., Chin, M., Tegen, I., et al.: Sources and distribution of dust aerosols with the GOCART model, J. Geophys. Res., 106, 20 225-20 273, 2001.

Gruber, N. and Sarmiento J. L.: Global patterns of nitrogen fixation and denitrification, Global Biogeochem. Cy., 11, 235-266, 1997.

Gruber, N.: The dynamics of the marine nitrogen cycle and its influence on atmospheric $\mathrm{CO} 2$ variations, in: The Ocean Carbon Cycle, edited by: Follow, M. and Orguz, T., Springer, New York, 97-148, 2004.

Howell, E. A., Doney, S. C., Fine, R. A., and Olsen, D. B.: Geochemical estimates of denitrification in the Arabian Sea and the Bay of Bengal during WOCE, Geophys. Res. Lett., 24, 25392552, 1997.

Hutchins, D. A., Fu, F. X., Zhang, Y., et al.: $\mathrm{CO}_{2}$ control of Trichodesmium nitrogen fixation, photosynthesis, growth rates and elemental ratios: Implications for past, present and future ocean biogeochemistry, Limnol. Oceanogr., 52, 1293-1304, 2007.

Jickells, T. D. and Spokes, L. J.: The Biogeochemistry of Iron in Seawater, edited by: Turner, D. R. and Hunter, K., Wiley, UK, 85-121, 2001.

Jickells, T. D., An, Z. S., Andersen, K. K., et al.: Global iron connections between desert dust, ocean biogeochemistry, and climate, Science, 308, 67-71, 2005.

Keeling, C. D., Piper, S. C., Bacastow, R. B., Wahlen, M., Whorf, T. P., Heimann, M., and Meijer, H. A.: Exchanges of Atmospheric $\mathrm{CO} 2$ and $13 \mathrm{CO} 2$ with the Terrestrial Biosphere and Oceans from 1978 to 2000, I Global Aspects, SIO Reference No. 01-06, 2001. Lam, P. J., Bishop, J. K. B., Henning, C. C., Marcus, M. 
A., Waychunas, G. A., and Fung, I. Y.: Wintertime phytoplankton bloom in the subarctic Pacific supported by continental margin iron, Global Biogeochem. Cy., 20, GB1006, doi:10.1029/2005GB002557, 2006.

Le Quéré, C., Aumont, O., Bopp, L., et al.: Two decades of ocean CO2 sink and variability, Tellus B, 55, 649-656, 2003.

Lipschulz, F., Wofsy, S., Ward, B., Codispoti, L., Friedrich, G., and Elkins, J.: Bacterial transformations of inorganic nitrogen in the oxygen deficient waters of the eastern tropical South Pacific, Deep Sea Res., Part I, 37, 1513-1541, 1990.

Madec, G., Delecluse, P., Imbard, M., and Lévy, C.: OPA8.1 Ocean general circulation model reference manual, Notes du pole de model, 11, 91PP., Inst. Pierre-Simon Laplace, Paris, 1990.

Mahaffey, C, Michaels, A. F., and Capone, D. G.: The conundrum of marine n-2 fixation, Am. J. Sci., 305, 546-595, 2005.

Mahowald, N. M. and Luo, C.: A less dusty future?, Geophys. Res. Lett., 30, 1903, doi:10.1029/2003GL017880, 2003.

Mahowald, N. M., Muhs, D. R., Levis, S., et al.: Change in atmospheric mineral aerosols in response to climate: last glacial period, modern and doubled carbon dioxide climates, J. Geophys. Res., 111, D10202, doi:10.1029/2005JD006653, 2006.

Mahowald, N. M.: Anthropocene changes in desert area: Sensitivity to climate model predictions, Geophys. Res. Lett., 34, L18817, doi:10.1029/2007GL030472, 2007.

Martin, J. H.: Glacial-Interglacial $\mathrm{CO}_{2}$ Change: the iron hypothesis, Paleoceanography, 5, 1-13, 1990.

Michaels, A. F., Karl, D. M., and Capone, D. G.: Element stoichiometry, new production nitrogen fixation, Oceanography, 14, 68-77, 2001.

Middleberg, J. J., Soetaert, K., Herman, P. M. J., and Heip, C. H. R.: Denitrification in marine sediments: A model study, Global Biogeochem. Cy., 10, 661-673, 1996.

Moore, J. K., Doney, S. C., Lindsay, K., Mahowald, N. M., and Michaels, A. F.: $\mathrm{N}$ fixation amplifies the ocean biogeochemical response to decadal timescale variations in mineral dust deposition, Tellus B, 58, 560-572, 2006.

Moore, J. K. and Doney, S. C.: Iron availability limits the ocean nitrogen inventory stabilizing feedback between marine denitrification and nitrogen fixation, Global Biogeochem. Cy., 21, GB2001, doi:10.1029/2006GB002762, 2007.

Moore, J. K. and Braucher, O.: Sedimentary and mineral sources of dissolved iron to the World Ocean, Biogeosciences Discuss., 4, 1279-1327, 2007, http://www.biogeosciences-discuss.net/4/1279/2007/.

Nakicenovic, N. and Swart, R. (Eds.): Special Report on Emissions Scenarios, A Special Report of Working Group III of the Intergovernmental Panel on Climate Change, Cambridge University Press, Cambridge, United Kingdom and New York, NY, USA, 599 pp., 2000.

Parekh, P., Dutkiewicz, S., Follows, M. J., and Ito, T.: Atmospheric carbon dioxide in a less dusty world, Geophys. Res. Lett., 33, L03610, doi:10.1029/2005GL025098, 2006.

Raven, J. A.: Predictions of Mn and Fe use efficiencies of phototrophic growth as a function of light availability for growth and of C assimilation pathway, New. Phytol., 116, 1-18, 1990.
Redfield, A. C.: On the proportions of organic derivations in sea water and their relation to the composition of plankton, James Johnston Memorial Volume, Liverpool, 176-192, 1934.

Rueter, J. G., Hutchins, D. A., Smith, R. W., and Unsworth, N. L.: Iron nutrition of Trichodesmium, in: Marine Pelagic Cyanobacteria: Trichodesmium and other diazotrophs, edited by: Carpenter, E. J., Kluwer Academic Publishers, Dordecht, 289-306, 1992.

Sabine, C. L., Feely, R. A., Gruber, N., et al.: The oceanic sink for anthropogenic CO2, Science, 305, 367-371, 2004.

Sarmiento, J. L., Gruber, N., Brzezinski, M. A., and Dunne, J. P.: High latitude control of thermocline nutrients and low latitude productivity, Nature, 427, 56-60, 2004a.

Sarmiento, J. L., Slater, R., Barber, R., et al.: Response of ocean ecosystems to climate warming, Global Biogeochem. Cy., 18, GB3003, doi:10.1029/2003GB002134, 2004b.

Sedwick, P. N., Sholkovitz, E. R., and Church, T. M.: Impact of anthropogenic combustion emissions on the fractional solubility of aerosol iron: Evidence from the Sargasso Sea, Geochem. Geophys. Geosyst., 8, Q10Q06, doi:10.1029/2007GC001586, 2007.

Soetaert, K., Middleberg, J. J,. Herman, P. M. J, and Buis, K.: On the coupling of benthic and pelagic biogeochemical models, Earth Sci. Rev., 51, 173-201, 2000.

Sunda, W. G. and Huntsman, S. A.: Interrelated influence of iron, light and cell size on marine phytoplankton growth, Nature, 390, 389-392, 1997.

Tagliabue, A. and Arrigo, K. R.: Processes governing the supply of iron to phytoplankton in stratified seas, J. Geophys. Res., 111, C06019, doi:10.1029/2005JC003363, 2006.

Takeda, S.: Influence of iron availability on nutrient consumption ratio of diatoms in oceanic waters, Nature, 393, 774-777, 1998.

Tegen, I., Werner M., Harrison S. P., and Kohlfeld, K. E.: Relative importance of climate and land use in determining present and future global soil dust emission, Geophys. Res. Lett., 31, L0515, doi:10.1029/2003GL019216, 2004.

Timmermann, R., Goose, H., Madec, G., Fichefet, T., Ethé, C., and Duliére, V.: On the respresentation of high latitude processes in the ORCALIM global coupled sea ice-ocean model, Ocean Modell., 8, 175-201, 2003.

Timmermans, K. R., van der Wagt, B., and de Baar, H. J. W.: Growth rates, half saturation constants, and silicate, nitrate, and phosphate depletion in relation to iron availability of four large, open ocean diatoms from the Southern Ocean, Limnol. Oceanogr., 49, 2141-2151, 2004.

Tyrrell, T., Merico, A., Waniek, J. J.: The relative influences of nitrogen and phosphorous on oceanic primary production, Nature, 400, 525-531, 1999.

Tyrrell, T. et al.: Effect of seafloor depth on phytoplankton blooms in high-nitrate, low-chlorophyll (HNLC) regions, J. Geophys. Res., 110, G02007, doi:10.1029/2005JG000041, 2005.

Wanninkhof, R.: Relationship between wind-speed and gasexchange over the ocean, J. Geophys. Res., 97, 7373-7382, 1992. 